\section{Analisis Rencana Pemekaran Desa dan Kecamatan di Kabupaten Kotawaringin Barat: Sebuah Skenario}

\author{
Hendra Try Ardianto 1) *, Laila Kholid \\ Alfirdaus 2) \\ 1 Program Studi Ilmu Pemerintahan, \\ Universitas Diponegoro. Jalan Professor \\ Soedarto SH, Tembalang, Kec. Tembalang, \\ Kota Semarang, Jawa Tengah 50139 \\ Indonesia. \\ 2 Program Studi Ilmu Pemerintahan, \\ Universitas Diponegoro. Jalan Professor \\ Soedarto SH, Tembalang, Kec. Tembalang, \\ Kota Semarang, Jawa Tengah 50139 \\ Indonesia.
}

* Korespondensi Penulis. E-mail: hendratrya@lecturer.undip.ac.id

Abstrak
Artikel ini bertujuan memaparkan
bagaimana skenario pemekaran kecamatan
dan desa di Kabupaten Kotawaringin Barat,
Provinsi Kalimantan Tengah. Disebut
skenario karena cara analisisnya bukan
berdasarkan dinamika tuntutan pemekaran,
melainkan lebih pada bagaimana
kesesuaian rencana pemekaran dengan tata
regulasi yang ada, terutama UU No $9 / 2015$
tentang Pemerintah Daerah, UU No.6/2014
tentang Desa dan PP Nomor $17 / 2018$
tentang Kecamatan. Argumen artikel ini
menunjukkan bahwa kebutuhan akan
pemekaran kecamatan dan desa di
kabupaten Kotawaringin Barat sudah tidak
terhindarkan, mengingat luasan wilayah
yang terlampau besar menjadi penghambat
pembangunan dan pelayanan publik.
Hasilnya, setidaknya ada dua skenario yang
bisa dilakukan, yakni jangka pendek dengan
penataan ulang kecamatan baru dan jangka
panjang dengan pemekaran beberapa desa
potensial. Dengan dua skenario itu, analisis
artikel ini menyuguhkan signifikansi secara

praktis bagaimana Kabupaten Kotawaringin Barat melakukan pemekaran agar mampu mendapatkan minimal 8 kecamatan.

Kata kunci: desa; kecamatan; pemekaran

\section{Analysis of Village and Sub-district \\ Proliferation Plans in Kotawaringin Barat: A Scenario}

\section{Abstract}

This article aims to describe the scenario for the proliferation of villages and sub-districts in Kotawaringin Barat Regency, Central Kalimantan Province. It is called a scenario because the method of analysis is not based on the dynamics of the demands for proliferation, but rather on how the proliferation plan fits into existing regulations, especially Law No. 9/2015 about Regional Government, Law No.6/2014 about Villages, Government Regulation (PP) No.17/2018 about Sub-distric.. The argument of this article shows that the need for the proliferation of villages and subdistricts in Kotawaringin Barat regency, is inevitable, considering that the large area is an obstacle to development and public services. As a result, there are at least two scenarios that can be carried out, namely: the short term by rearranging new subdistricts and the long term by splitting several potential villages. With these two scenarios, this article presents the practical significance of how Kotawaringin Barat district expanded to get a minimum of 8 districts.

Keywords: village; sub-distric; proliferation 


\section{A. PENDAHULUAN}

Wajah umum wilayah Indonesia pasca Orde Baru adalah lahirnya provinsi, kabupaten, dan kota-kota baru. Hal ini merupakan hasil perubahan politik pasca reformasi, yang menggeser corak tata pemerintahan yang sentralistik (Orde Baru) menjadi sistem desentralistik. Dalam tempo dua dekade, dari 26 provinsi dan 293 kabupaten/kota telah mengalami kenaikan drastis menjadi 34 provinsi yang terdiri dari 416 kabupaten dan 98 kota. Itu pun masih ada sekitar 314 usulan pemekaran daerah otonomi baru (DOB) yang masuk di Kementrian Dalam Negeri (Setkab.go.id, 2019). Usulan ini menunjukkan bahwa masih banyak daerah yang terus menyuarakan adanya pemisahan wilayah dari wilayah asalnya. Hal ini berbanding terbalik dengan tidak adanya usulan penggabungan wilayah di Indonesia.

Akibat tingginya usulan pemekaran wilayah baru, maka pemerintah terus mengevaluasi hasil dari pemekaran. Tidak tanggungtanggung, regulasi yang dipakai pun berulang kali terus berubah. Setidaknya sudah empat kali perubahan pada Undang-Undang tentang Pemerintah Daerah, yakni mulai UU No.22/1999, UU No.32/2004, UU No 23/2014, dan terakhir UU No 9/2015. Karena usulan pemekaran yang terus bermunculan, maka sejak 2014 segala usulan pemekaran DOB di moratorium. Hal ini dilakukan karena hasil evaluasi pemekaran dirasa kurang berdampak signifikan pada kesejahteraan masyarakat, serta ada persoalan terkait dengan kapasitas keuangan negara (Kompas.com, 2020).
Di tengah moratorium usulan pembentukan DOB untuk provinsi dan kabupaten/kota baru ini, masih banyak usulan dari bawah (grassroot) untuk melakukan pemekaran kecamatan dan desa, salah satunya di Kabupaten Kotawaringin Barat (selanjutnya ditulis Kobar), Provinsi Kalimantan Tengah. Munculnya usulan ini lantaran kondisi sosial ekonomi di Kotawaringin Barat jauh dari kata ideal. Luas wilayah yang terlampau luas, kadang kala menyuliskan berbagai langkah pembangunan dan penyediaan layanan publik. Sebagai sebuah ilustrasi, desa terkecil di Kobar memiliki luas hampir sama dengan luas Kota Magelang, sedangkan desa terluas memiliki luasan lebih dari 25 kali luas Kota Magelang di Jawa. Hal ini tentu saja menjadi hambatan dalam banyak persoalan terkait layanan publik disana.

Padahal, sebagaimana diketahui, tugas seorang camat tidaklah sedikit. Menurut Peraturan Pemerintah No.17 Tahun 2018 Pasal 10, Camat memiliki tugas meliputi penyelenggaraan urusan pemerintahan umum, mengordinasikan agenda pemberdayaan masyarakat, memelihara ketentraman dan ketertiban umum, menerapkan dan menegakkan peraturan daerah dan peraturan kepala daerah, memelihara prasarana dan sarana publik, mengoordinasikan penyeleng-garaan pemerintahan di tingkat kecamatan, membina dan mengawasi penyelenggaraan pemerintahan desa dan melaksanakan tugas lainnya sesuai aturan perundang-undangan. Mengingat tugas sebanyak ini, dengan kondisi wilayah kecamatan di Kobar yang terlampau luas, maka masuk akal 
rasanya jika penataan ulang wilayah kecamatan di Kobar menjadi solusi jangka panjang. Hal ini bertujuan untuk mengoptimalkan kualitas pelayanan publik yang lebih merata.

Tabel 1. Informasi Dasar Kecamatan di Kabupaten Kotawaringin Barat 2017

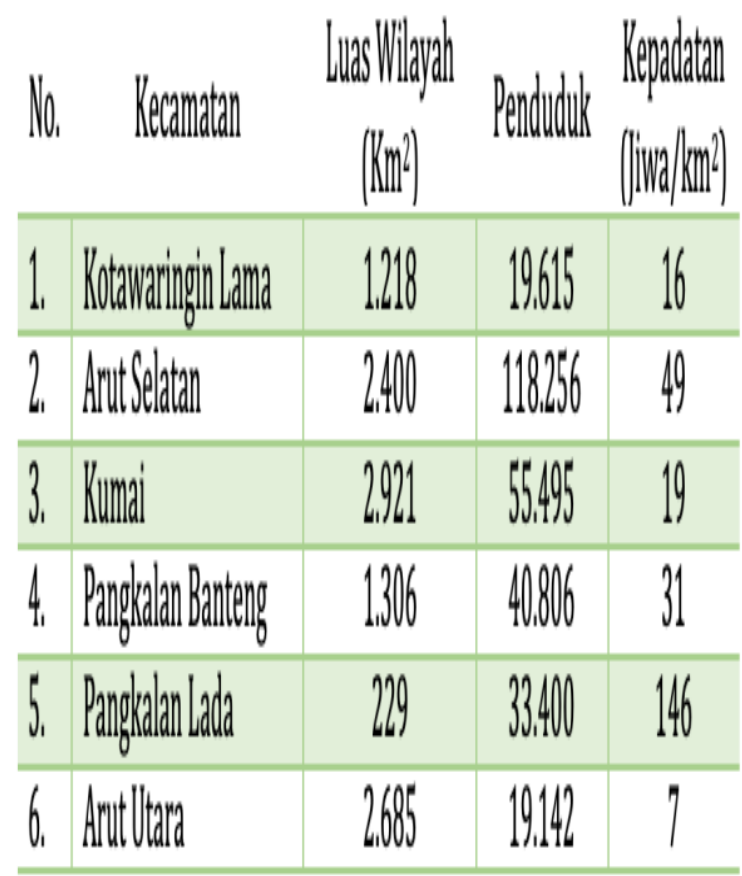

Sayangnya, ketentuan pemekaran yang diatur dalam PP Nomor 17 Tahun 2018 tentang Kecamatan memiliki aturan yang sangat sulit diterapkan dalam konteks Pulau Kalimantan, khususnya di Kabupaten Kobar. Penetapan sepihak dari pemerintah pusat tentang jumlah minimal desa/kelurahan untuk pembentukan kecamatan membuat Kabupaten Kobar sulit mewujudkan pemekaran kecamatan. Padahal, masalah utama tidak maksi-malnya pembangunan dan pelayanan publik selama ini adalah karena satu pemerintahan kecamatan harus menau-ngi beberapa desa yang luasnya sangat besar dan belum memiliki infrastruktur (utamanya jalan) yang memadai. Ikhtiar untuk mendekatkan pembangunan dan layanan publik melalui pemekaran kecamatan pun terganjal dengan ketentuan regulasi semacam itu.

Sebagai contoh, Kecamatan Kumai di Kabupaten Kobar meski memiliki luas wilayah $2.921 \mathrm{Km}^{2}$-nyaris 3 kali lipat luas wilayah Kabupaten Rembang (1.014 Km2)- tetap sulit dimekarkan menjadi dua kecamatan karena hanya memiliki 18 desa/kelurahan. Hal ini sangatlah aneh mengingat beberapa desa di kecamatan ini harus menempuh puluhan kilometer hanya untuk datang ke ibukota kecamatan. Sebagai misal, Desa Sabuai yang harus menempuh perjalanan 63,2 kilometer hanya untuk ke Kantor Kecamatan di Kumai. Tidak hanya itu, Desa Sungai Cabang bahkan tidak memiliki akses darat untuk menuju ibukota kecamatan, melainkan harus melalui jalur laut.

Pada titik ini, pemekaran desa dan kecamatan di Kobar menemukan relevansinya. Bagaimana tidak, jika disisir satu per satu keadaan di masingmasing kecamatan tampak ketidakmerataan sosial-ekonomi masyarakat. Kecamatan Kumai berbatasan langsung dengan pantai dan memiliki pelabuhan, tetapi desadesanya berjarak terlalu jauh dengan pusat kecamatan (kurang lebih $50 \mathrm{~km}$ ). Kecamatan Arut Selatan adalah pusat segalanya, baik pemerintahan, pendidikan dan ekonomi. Kemudian Pangkalan Banteng merupakan kecamatan yang dipadati warga ekstransmigran. Kecamatan Kotawaringin Lama adalah daerah yang tidak terlalu padat namun mulai bergeliat ekonomi- 
nya, khususnya di kawasan Riam Durian dan Despot. Sedangkan Kecamatan Pangkalan Lada adalah kecamatan paling kecil wilayahnya namun paling padat penduduknya. Sebaliknya, Arut Utara merupakan kecamatan yang cukup luas, tetapi penduduknya paling sedikit.

Sudah sepantasnya kondisi wilayah sebagaimana yang ada di Kobar seperti itu memerlukan upaya pemekaran wilayah, khususnya untuk desa dan kecamatan. Jika keadaan semacam itu terus berlangsung, maka ketidak-merataan sosial-ekonomi dari pemba-ngunan akan terus terjadi, dan pelayanan publik kepada masyatakat akan berjalan tidak maksimal. Hal seperti itu bisa berdampak buruk bagi kesejahteraan masyarakat lokal dalam waktu yang lama.

\section{B. TEORI (Literature Review)}

Salah satu alasan melakukan pemekaran desa dan kecamatan adalah untuk mendorong pemerataan pembangunan dan mendekatkan layanan publik kepada warga, khususnya yang ada di tingkat administrasi terbawah. Ini berarti, pemekaran merupakan wujud penataan ulang terhadap administrasi desa dan atau kelurahan di dalam masing-masing wilayah administrasi kecamatan. Hal ini penting mengingat urgensi pemekaran yang kian mendesak dan regulasi yang terlampau ketat. Seandai-nya pemerintah pusat melonggarkan aturan ini, mungkin situasi jauh lebih sederhana. Namun, mengharapkan pemerintah pusat merevisi aturan dalam waktu dekat, tentu saja langkah yang penuh ketidak-pastian. Untuk itu, penulis membuat analisis kemungkinan penataan ulang bagi administrasi wilayah kecamatan yang baru.

Dalam melakukan analisis ini, penulis menjadikan tiga payung regulasi sebagai kaca mata teoritis bagaimana melakukan analisis terkait dengan pemekaran desa dan kecamatan sekaligus. Ketiga regulasi itu adalah UU No 9/2015 tentang Pemerintah Daerah, UU No.6 Tahun 2014 tentang Desa dan PP Nomor 17 Tahun 2018 tentang Kecamatan. Perihal bagaimana pemekaran pemekaran desa/kelurahan, terdapat 5 tahapan dan 9 syarat yang harus dipenuhi. Sedangkan untuk pemekaran kecamatan, ketentuannya menyangkut 3 kualifikasi utama, yakni kualifikasi persyaratan dasar, persyaratan teknis, dan persyaratan administratif. Adapun penjelasan ketentuan-ketentuan terkait tahapan, syarat, dan kualifikasi tersebut akan dilakukan secara dalam pembahasan nanti.

Pentingnya pemekaran ini dikonfirmasi oleh beberapa studi yang menunjukkan dampak positif adanya pemekaran wilayah baru terhadap pembangunan di suatu daerah. Dampak positif dari pemekaran wilayah misalkan diamini oleh Santika et al., (2018) yang berargumen bahwa ditemukan adanya peningkatan positif pada pertumbuhan perekonomian, pemerataan ekonomi, dan pembangunan daerah pada Kabupaten Lombok Utara setelah dimekarkan pada 2017. Dampak positif semacam ini juga terjadi di Provinsi Papua, dimana ada pengaruh signifikan dari pemekaran terhadap menurunnya tingkat 
kemiskinan di provinsi itu (Riani \& Pudjihardjo, 2012).

Pengaruh positif seperti itu biasanya terjadi karena meningkatnya pembangunan infrastruktur baru yang membantu membuka berbagai akses pembangunan lainnya, khususnya untuk mempermudah mobilitas dan akses terhadap lokasi tertentu (Harahap, 2015). Hal seperti itu sebagaimana terjadi di Desa Kapu Jaya Kecamatan Palangga Kabupaten Konawe Selatan, dimana pembangunan pembangunan infra-struktur jalan, sarana dan prasarana kesehatan dan pendidikan semakin meningkat sejak desa tersebut dimekarkan (Mudana et al., 2016). Peningkatan kualitas infrastruktur seperti itu juga terjadi di Kabupaten Minahasa Selatan (Panambunan et al., 2018), kemudian di Desa Sungai Bendung Air Kecamatan Kayu Aro Kabupaten Kerinci (Bustami, 2018), maupun di Desa Kramat Jaya Kecamatan Malausma Kabupaten Majalengka (Lutpiah, 2016).

Selain berdampak pada perkembangan infrastruktur baru, pemekaran desa dan kecamatan juga berpengaruh pada peningkatan kualitas layanan publik. Sebagaimana terjadi di Desa Sadar Kecamatan Bone-Bone Kabupaten Luwu Utara, pelayanan Akta Kelahiran dan Kartu Keluarga menjadi semakin baik sejak pemekaran, baik dari sisi prosedur, waktu, biaya, hingga sumber daya aparaturnya (Kartini, 2016). Dampak positif seperti itu juga terjadi di Kecamatan Tombariri Timur, Kabupaten Minahasa (Yosephus, 2014). Selain layanan adminsitratif, pemekaran juga berdampak cukup baik pada peningkatan layanan pendidikan sebagaimana di Kabupaten Kepulauan Talaud (Polakitang, 2013).

Dengan harapan atas dampak yang lebih positif pada peningkatan kualitas pembangunan dan perbaikan layanan publik, maka kebutuhan akan pemekaran desa dan kecamatan ini menjadi relevan bagi daerah-daerah tertentu, salah satunya Kabupaten Kotawaringin Barat yang memiliki wilayah yang terlampau luas, sulit diakses, dan tidak meratanya sosioekonomi di wilayah tersebut. Studi ini dimaksudkan untuk melihat bagaimana skenario pemekaran wilayah desa dan kecamatan disana.

\section{METODE}

Dalam pengerjaan artikel ini, penulis melakukan penelitian dengan menggunakan metode kualitatif deskriptif, yang menggabungkan dengan studi literatur terhadap berbagai data sekunder. Dalam penggalian data, penulis melakukanm studi lapangan dengan memadukan beberapa pola penggalian data seperti wawacara mendalam, FGD (Focused Group Discussion) dan observasi nonpartisipan. Lokasi penelitian ini adalah Kabupaten Kota Waringin Barat Tahun 2019 dengan mencakup seluruh wilayah kecamatan yang ada.

Studi literatur bertujuan untuk memetakan regulasi yang ada untuk dijahit sebagai instrumen penelitian guna menentukan persyaratan dasar peme-karan yang meliputi, persyaratan administratif, teknis dan fisik kewilayahan. Selain itu, studi literatur juga dipakai untuk mengidentifikasi karakteristik desa dan kecamatan di Kabupaten Kotawaringin Barat. 
Sedangkan untuk wawancara, penulis melakukan wawancara dengan berbagai pihak, mulai dari pihak pemerintah (Wakil Bupati, Ketua DPRD, Kepala Badan Pemberdayaan Masyarakat Desa, hingga camat dan kepala desa) dan juga pihak masyarakat (LSM, pelaku bisnis, tokoh masyarakat). Adapun untuk FGD, penulis melakukan satu kali yang difasilitasi oleh Badan Pemberdayaan Masyarakat Desa dengan diadakannya FGD bersama perwakilan seluruh perangkat kecamatan dan desa di Pangkalan Bun.

Data yang telah terkumpul kemudian dikatagorisasikan dan dipilah-pilah sesuai dengan variabel teoritis yang digunakan. Selanjutnya, data yang dikategorisasikan dimasukkan pada operasionalisasi konsep yang digunakan, khususnya untuk melihat bagaimana kualifikasi persyaratan pemekaran dikerjakan. Beberapa data-data yang dianggap tidak relevan direduksi dari basis analisis. Terakhir, penarikan kesimpulan diambil setelah beberapa parameter yang ditentukan telah dipenuhi dengan baik.

\section{HASIL DAN PEMBAHASAN}

1. Penataan Ulang Administrasi Wilayah Kecamatan

Setelah melakukan analisis dokumen dan penelitian langsung di lapangan, tim penulis melihat jalan menuju rencana pemekaran kecamatan bisa dilakukan jika didahului dengan penataan ulang wilayah administratif kecamatan. Untuk melakukan ini, penulis akan membagi rencana penataan wilayah dalam dua rencana, yakni jangka pendek dan jangka panjang. Rencana jangka pendek ini diestimasikan membutuhkan waktu sekitar 1 sampai 3 tahun, sedangkan untuk rencana jangka panjang diperkirakan membutuhkan waktu 3 hingga 5 tahun atau lebih. Pembedaan rencana ini dilakukan karena tidak mungkin melakukan pemekaran kecamatan serta merta tanpa melihat ketentuan regulasi yang sangat ketat itu.

\section{a) Rencana Penataan Ulang Administrasi Wilayah Jangka Pendek}

Disebut jangka pendek karena proses menuju rencana pemekaran bisa dilakukan sejak saat ini juga. Pemerintah daerah sudah bisa melakukan proses administratif maupun proses politis untuk mulai langkah-langkah penataan ulang administrasi wilayah kecamatan. Tujuannya jelas, yakni untuk memenuhi syarat minimal 10 desa/kelurahan agar bisa dilanjutkan untuk proses pembentukan kecamatan baru.

Adapun hasil analisis yang dilakukan penulis, menunjukkan ada 4 wilayah kecamatan yang perlu ditata ulang wilayah administratifnya, yakni Kecamatan Kumai, Kecamatan Arut Selatan, Kecamatan Pangkalan Lada dan Kecamatan Arut Utara. Sedangkan untuk Kecamatan Kotawaringin Lama dan Kecamatan Pangkalan Banteng, dalam waktu dekat tidak membutuhkan penataan ulang dahulu. Secara sederhana, analisis penataan wilayah kecamatan yang penulis tawarkan sebagaimana ada dalam tabel 2 . 
Tabel 2. Tawaran Penataan Wilayah Administratif Baru

\begin{tabular}{|c|c|c|c|c|}
\hline $\mathrm{N}_{0}$. & Kecamatan & Status & $\begin{array}{c}\text { Desa/kelurahan } \\
\text { ditambah } \\
\end{array}$ & $\begin{array}{l}\text { Desa/kelurahan } \\
\text { dikurangi }\end{array}$ \\
\hline 1. & $\begin{array}{c}\text { Kotawaringin } \\
\text { Lama }\end{array}$ & $\begin{array}{c}\text { Tidak } \\
\text { Berubah } \\
\end{array}$ & & 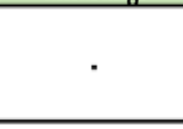 \\
\hline 2. & Arut Selatan & Berubah & $\begin{array}{l}\text { Desa Nanga Mua } \\
\text { \& Desa Purbasari }\end{array}$ & $\begin{array}{l}\text { Desa Taniung } \\
\text { Putri\& Desa } \\
\text { Tanjung } \\
\text { Terantang }\end{array}$ \\
\hline 3. & Kumai & Berubah & $\begin{array}{c}\text { Desa Tanjung } \\
\text { Putri \& Desa } \\
\text { Tanjung } \\
\text { Terantangng }\end{array}$ & - \\
\hline 4. & $\begin{array}{c}\text { Pangkalan } \\
\text { Banteng }\end{array}$ & $\begin{array}{l}\text { Tidak } \\
\text { Berubah }\end{array}$ & - & . \\
\hline 5. & $\begin{array}{c}\text { Pangkalan } \\
\text { Lada } \\
\end{array}$ & Berubah & . & Desa Purbasari \\
\hline 6. & Arut Utara & Berubah & & Desa Nanga Mua \\
\hline
\end{tabular}

Dengan melakukan penataan ulang sebagaimana tabel 2, maka syarat jumlah minimal desa/kelurahan untuk pembentukan kecamatan baru bisa dilakukan. Hasil dari penataan ulang ini akan menghasilkan tata wilayah administratif baru, yakni Kecamatan Kumai menjadi 20 desa/kelurahan; Kecamatan Arut Utara menjadi 10 desa/kelurahan; Kecamatan Pangkalan Lada menjadi 10 desa, sedangkan Kecamatan Arut Selatan tetap berjumlah 20 desa/kelurahan, hanya berubah tata wilayahnya saja. Adapun Kecamatan Kotawaringin Lama dan Kecamatan Pangkalan Lada tidak mengalami perubahan, tetap dengan 17 desa/kelurahan di masing-masing kecamatannya.

Setelah melakukan penataan ulang wilayah administratif kecamatan tersebut, maka setidaknya Kabupaten Kobar bisa melakukan pemekaran kecamatan baru minimal di dua wilayah, yakni Kecamatan Arut Selatan dan Kecamatan Kumai. Sebab, kedua kecamatan ini sudah memenuhi syarat minimal 10 desa/kelurahan untuk pembentukan kecamatan baru. Untuk melakukan pemekaran wilayah kecamatan, maka penulis menawarkan rencana sebagaimana tercantum dalam tabel 3.

Tabel 3. Rencana Pemekaran Kecamatan Kumai dan Arut Selatan

\begin{tabular}{|c|l|l|}
\hline \multicolumn{4}{|c|}{ Kecamatan Kumai } \\
\hline 1. & $\begin{array}{l}\text { Kecamatan } \\
\text { Induk } \\
\text { (7 desa, 3 } \\
\text { kelurahan) }\end{array}$ & $\begin{array}{l}\text { Desa Sungai Sikonyer; Desa Sungai } \\
\text { Bedaun; Kelurahan Kumai Hulu, } \\
\text { Kelurahan Kumai Hilir; Kelurahan } \\
\text { Candi; Desa Batu Belaman; Desa } \\
\text { Sungai Tendang; Desa Pangkalan Satu; } \\
\text { Desa Bumi Harjo; Desa Sungai Kapitan }\end{array}$ \\
\hline 2. & $\begin{array}{l}\text { Kecamatan } \\
\text { Pemekaran } \\
(10 \text { desa) }\end{array}$ & $\begin{array}{l}\text { Desa Tanjung Terantang; Desa } \\
\text { Tanjung Putri; Desa Sabuai; Desa } \\
\text { Sabuai Timur; Desa Keraya; Desa } \\
\text { Teluk Bogam; Desa Sungai Bakau; } \\
\text { Desa Kubu; Desa Teluk Pulai; Desa } \\
\text { Sungai Cabang }\end{array}$ \\
\hline 1. & $\begin{array}{l}\text { Kecamatan } \\
\text { Induk } \\
(4 \text { desa, } \\
\text { kelurahan) }\end{array}$ & $\begin{array}{l}\text { Desa Kumpai Batu Bawah; Desa } \\
\text { Kumpai Batu Atas; Desa Pasir } \\
\text { Panjang; Kelurahan Mendawai; } \\
\text { Kelurahan Mendawai Seberang; } \\
\text { Kelurahan Raja; Kelurahan Sidorejo; } \\
\text { Desa Madurejo; Kelurahan Baru; } \\
\text { Kelurahan Raja Seberang }\end{array}$ \\
\hline 2. & $\begin{array}{l}\text { Kecamatan } \\
\text { Pemekaran Nanga Mua; Desa Umpang; Desa } \\
(10 \text { desa) }\end{array}$ & $\begin{array}{l}\text { Runtu; Desa Sulung; Desa Kenambui; } \\
\text { Desa Rangda; Desa Medang Sari; Desa } \\
\text { Natai Raya; Desa Natai Baru; Desa } \\
\text { Purbasari }\end{array}$ \\
\hline
\end{tabular}

Jika pemekaran kecamatan baru dijalankan berdasar skema yang ada, maka tentu saja akan menciptakan kegaduhan dan polemik di akar rumput. Desa-desa yang mengalami perubahan wilayah administratif di kecamatan sangat mungkin akan menolak rencana ini. Masyarakat Desa Nanga Mua akan tetap terisolir akibat berpindah wilayah administratif, terlebih posisi geografisnya sebenarnya lebih dekat dengan Kelurahan Pangkut sebagai 
Ibukota Kecamatan Arut Utara. Begitu juga dengan Desa Purbasari, masyarakat desa tersebut akan menempuh jarak dua kali lipat dibanding harus ke Kelurahan Pandu Sanjaya di Kecamatan Pangkalan Lada daripada harus bergabung dengan kecamatan baru lainnya. Sedangkan Desa Tanjung Putri dan Desa Tanjung Terantang, tidak ada kepastian bahwa mereka akan menerima gagasan perubahan ini karena posisi geografis mereka tetap saja terisolir dalam sudut pandang jarak tempuh ke ibukota kecamatan yang baru.

Kegaduhan akan semakin meningkat ketika sudah menyangkut calon ibukota kecamatan baru hasil pemekaran. Masing-masing desa akan cenderung mengusulkan wilayahnya yang akan menjadi ibukota kecamatan baru. Sejauh observasi penulis, saat ini sudah muncul dua usulan terkait calon ibukota kecamatan baru untuk rencana pemekaran Kecamatan Kumai, yakni Desa Kubu dan Desa Teluk Bogam. Beberapa birokrat kabupaten cenderung menyuarakan pilihan ibukota baru di Desa Kubu, meski hasil wawancara tim peneliti saat Focus Group Discussion (FGD) pada 21 November, perwakilan dari Desa Kubu menyatakan "Masyarakat kami biasa saja, tidak memaksakan harus menjadi ibukota". Sebaliknya, aspirasi dari Desa Teluk Bogam jauh lebih berkeinginan agar menjadi calon ibukota kecamatan baru, dengan telah menyiapkan lahan kosong sebesar 25 Ha untuk infrastruktur kantor kecamatan.

Sedangkan untuk calon ibukota pemekaran dari Kecamatan Arut Selatan, saat ini baru terdengar Desa
Runtu saja. Namun tidak menutup kemungkinan, jika rencana pemekaran sudah mendekati pelaksanaan, akan muncul aspirasi agar masing-masing desanya menjadi ibukota kecamatan pemekaran. Terlebih, jika Desa Runtu menjadi ibukota kecamatan yang dimekarkan, maka Desa Natai Raya, Desa Natai Baru, dan Desa Purbasari akan cenderung keberatan karena mengganggap jarak tempuh ke ibukota kecamatan lebih jauh dan sulit dibanding posisi mereka sebelumnya.

Artinya, rencana pemekaran kecamatan ini bukan langkah yang pasti mulus begitu saja, tetapi akan menciptakan pro dan kontra, baik ketika perubahan wilayah administratif dan terutama ketika penentuan ibukota kecamatan. Untuk itu, pemerintah daerah harus mengupayakan sosialisasi dan resolusi konflik sebaik mungkin agar polemik yang disebabkan oleh perubahan wilayah administratif baru tidak berlarut-larut menjadi konflik yang tidak terselesaikan. Pemerintah daerah harus melakukan koordinasi dengan DPRD untuk memuluskan misi ini. Sebab, hal ini membutuhkan upaya politik yang tidak ringan. Sangat disayangkan karena aturan PP Nomor 17 Tahun 2018 yang begitu ketat ini mengakibatkan tidak ada solusi yang bisa menyenangkan semua kalangan. Oleh karenanya, semua pihak perlu memberi perhatian secara serius terhadap persoalan ini, baik pemerintah daerah, DPRD, dan masyarakat.

\section{b) Rencana Penataan Wilayah Administratif Jangka Panjang}

Adapun yang dimaksud dengan penataan wilayah jangka panjang adalah penataan wilayah yang harus disiapkan 
Vol.2 No.2 Desember 2020

saat ini karena memakan proses yang jauh lebih lama. Secara sederhana, rencana jangka panjang ini merujuk pada rencana pemekaran desa/kelurahan baru yang jika bisa dilakukan dapat diarahkan untuk rencana pemekaran kecamatan di masa depan. Pemekaran desa dimasukkan sebagai rencana jangka panjang karena prosesnya tidak bisa instan, namun memakan waktu yang lebih lama. Secara sederhana, untuk melakukan pemekaran (pembentukan) desa setidaknya ada 5 tahapan.

1) Jika sudah memenuhi semua persyaratan dan ada kesepakatan dari masyarakat desa yang bersangkutan (terdapat berita acara), usulan bisa dilanjutkan dengan membentuk Desa Persiapan.

2) Desa Persiapan ini akan dievaluasi selama 1 hingga 3 tahun sebelum ditingkatkan statusnya menjadi Desa.

3) Pembentukan desa baru ini harus melalui mekanisme keputusan berupa Rancangan Peraturan Daerah (Perda) tentang Pembentukan Desa, yang disetujui oleh bupati, DPRD, lalu diajukan pada gubernur.

4) Gubernur akan melakukan proses evaluasi terhadap rancangan perda, dan jika gubernur menerima rancangan tersebut, maka gubernur akan memberikan nomor regristrasi dan diajukan untuk mendapatkan kode desa dari Menteri Dalam Negeri.
5) Pembentukan desa baru dinyatakan sah setelah diputuskan dalam perda tentang pembentukan desa baru.

Agar Pemerintah Kabupaten Kobar dapat mengajukan usulan pemekaran desa/kelurahan, yang pertama dilakukan adalah memenuhi syaratsyarat spesifik yang telah diatur dalam UU No.6 Tahun 2014 tentang Desa dan PP Nomor 17 Tahun 2018. Setidaknya ada 9 syarat yang harus dipenuhi sebelum pelakukan pemekaran desa/kelurahan, antara lain:

1) batas usia desa induk paling sedikit 5 (lima) tahun terhitung sejak pembentukan;

2) jumlah penduduk desa untuk wilayah Provinsi Kalimantan Tengah paling sedikit 1.500 (seribu lima ratus) jiwa atau 300 (tiga ratus) kepala keluarga; sedangkan untuk kelurahan paling sedikit 2.000 (dua ribu) jiwa atau 400 (empat ratus) kepala keluarga;

3) untuk wilayah Provinsi Kalimantan Tengah, luas wilayah kelurahan paling sedikit $7 \mathrm{~km} 2$, sedangkan untuk desa tidak disyaratkan secara jelas dalam aturan;

4) wilayah kerja yang memiliki akses transportasi antarwilayah;

5) sosial budaya yang dapat menciptakan kerukunan hidup bermasyarakat sesuai dengan adat istiadat Desa;

6) memiliki potensi yang meliputi sumber daya alam, sumber 
daya manusia, dan sumber daya ekonomi pendukung;

7) batas wilayah Desa yang dinyatakan dalam bentuk peta Desa yang telah ditetapkan dalam peraturan Bupati/ Walikota;

8) sarana dan prasarana bagi Pemerintahan Desa dan pelayanan publik; dan

9) tersedianya dana operasional, penghasilan tetap, dan tunjangan lainnya bagi perangkat Pemerintah Desa sesuai dengan ketentuan peraturan perundangundangan.

Guna memetakan ada berapa desa/kelurahan di Kabupaten Kobar yang potensial untuk dimekarkan, maka perlu untuk membuat overview sederhana terhadap beberapa syarat yang mudah diukur. Jika mencermati 9 syarat yang ada, maka syarat nomor 1 , 2, dan 3 relatif lebih mudah dipetakan atau diukur di atas kertas. Untuk itu, penulis akan memberi gambaran bagaimana desa/kelurahan di Kabupaten Kobar dibaca dalam perspektif syarat 1 hingga 3 . Adapun gambarannya bisa dilihat pada tabel 4 berikut ini.
Tabel 4. Sebaran Desa/Kelurahan yang Berpotensial dimekarkan

\begin{tabular}{|c|c|c|c|c|c|}
\hline No. & $\begin{array}{c}\text { Nama } \\
\text { Desa/Kelurahan }\end{array}$ & $\begin{array}{l}\text { Jumlah } \\
\text { Penduduk }\end{array}$ & $\begin{array}{c}\text { Jumlah } \\
\text { KK }\end{array}$ & $\begin{array}{l}\text { Luas Wilayah } \\
\qquad\left(\mathrm{Km}^{2}\right)\end{array}$ & $\begin{array}{c}\text { Asumsi } \\
\text { Potensi } \\
\text { Pemekaran }\end{array}$ \\
\hline \multicolumn{6}{|c|}{ Kecamatan Kotawaringin Lama } \\
\hline 1. & $\begin{array}{l}\text { Kelurahan } \\
\text { Kotawaringin Hilir }\end{array}$ & 3.517 & 1.015 & 520 & Tinggi \\
\hline 2. & Desa Riam Durian & 2.073 & 624 & 22.45 & Rendah \\
\hline \multicolumn{6}{|c|}{ Kecamatan Arut Selatan } \\
\hline 3. & $\begin{array}{l}\text { Desa Kumpai Batu } \\
\text { Atas }\end{array}$ & 3.062 & 808 & 30 & Rendah \\
\hline 4. & Desa Pasir Panjang & 11.673 & 3.194 & 162 & Tinggi \\
\hline 5. & $\begin{array}{l}\text { Kelurahan } \\
\text { Mendawai }\end{array}$ & 12.237 & 3.303 & 469 & Tinggi \\
\hline 6. & $\begin{array}{l}\text { Kelurahan } \\
\text { Mendawai Seberang }\end{array}$ & 2.233 & 609 & 26 & Rendah \\
\hline 7. & Kelurahan Madurejo & 21.192 & 5.503 & 26 & Rendah \\
\hline 8. & Desa Runtu & 5.156 & 1.485 & 504 & Tinggi \\
\hline \multicolumn{6}{|c|}{ Kecamatan Kumai } \\
\hline 9. & Desa Kubu & 3.990 & 763 & 122 & Rendah \\
\hline 10. & Desa Sungai Kapitan & 5.971 & 1.315 & 90 & Tinggi \\
\hline 11. & $\begin{array}{l}\text { Kelurahan Kumai } \\
\text { Hilir }\end{array}$ & 9.082 & 1.966 & 82 & Tinggi \\
\hline 12. & $\begin{array}{ll}\text { Desa } & \text { Sungai } \\
\text { Tendang } & \end{array}$ & 3.747 & 867 & 52 & Tinggi \\
\hline 13. & $\begin{array}{l}\text { Kelurahan Kumai } \\
\text { Hulu }\end{array}$ & 8.114 & 1.756 & 18 & Rendah \\
\hline 14. & Desa Sungai Bedaun & 5.384 & 1.456 & 403 & Tinggi \\
\hline 15. & Desa Bumi Harjo & 5.690 & 1.541 & 27,62 & Tinggi \\
\hline 16. & Desa Pangkalan Satu & 2.393 & 607 & 16,38 & Rendah \\
\hline \multicolumn{6}{|c|}{ Kecamatan Pangkalan Banteng } \\
\hline 17. & Desa Amin Jaya & 7.78 & 2.245 & 45 & Tinggi \\
\hline 18. & Desa Karang Mulya & 4.754 & 1.222 & 15 & Rendah \\
\hline 19. & Desa Arga Mulya & 3.147 & 969 & 150 & Tinggi \\
\hline 20. & $\begin{array}{ll}\text { Desa } & \text { Sungai } \\
\text { Bengkoang } & \end{array}$ & 5.481 & 1.612 & 40 & Tinggi \\
\hline 21. & Desa Sungai Pakit & 3.930 & 1.141 & - & Tinggi \\
\hline \multicolumn{6}{|c|}{ Kecamatan Pangkalan Lada } \\
\hline 22. & Desa Purbasari & 3.013 & - & 21 & Rendah \\
\hline 23. & Desa Sumber Agung & 3.041 & - & 32,1 & Rendah \\
\hline 24. & Desa Pandu Sanjaya & 11.769 & - & 25 & Tinggi \\
\hline \multicolumn{6}{|c|}{ Kecamatan Arut Utara } \\
\hline 25. & Kelurahan Pangkut & 10.973 & 3.314 & 238 & Tinggi \\
\hline 26. & Desa Nanga Mua & 2.843 & 821 & 444 & Tinggi \\
\hline
\end{tabular}

Keterangan:

- Tinggi : Berpotensi dimekarkan menjadi 3 wilayah administratif atau lebih

- Rendah : Berpotensi dimekarkan maksimal 2 wilayah administratif

Menilik pada tabel 3, setidaknya ada 26 desa/kelurahan yang memiliki potensi untuk dilakukan pemekaran desa/kelurahan. Analisis ini hanya berdasarkan asumsi terpenuhinya syarat 12 , dan 3 (mengasumsikan syarat 4 hingga 9 bisa terpenuhi di belakang hari), serta hanya rekaan atau modeling di atas kertas saja. Sebab, besar kemungkinan banyak sekali faktor yang membuat rencana pemekaran tidak bisa dilakukan, misal jumlah penduduk atau jumlah KK yang tidak merata sehingga gagal memenuhi syarat minimal, baik untuk desa/kelurahan induk maupun desa/kelurahan 
persiapan. Untuk itu, tim peneliti mengkategorikan beberapa kemungkinan pemekaran desa/kelurahan dalam dua tingkatan, yakni tinggi dan rendah. Dianggap memiliki potensi pemekaran tinggi jika jumlah penduduk, jumlah KK, dan luas wilayah masih ideal jika dibagi menjadi 3 bagian. Sedangkan memiliki potensi pemekaran rendah jika jumlah penduduk, jumlah KK, dan luas wilayah hanya cukup dibagi dalam 2 bagian.

Potensi di atas kertas tentu saja berbeda dengan kenyataan di lapangan. Hal ini dibuktikan dari usulan-usulan pemekaran desa bahkan muncul di desa/kelurahan yang tidak disebutkan di atas. Desa Sungai Hijau di Kecamatan Pangkalan Banteng misalkan, meski hanya memiliki luas $10 \mathrm{Km} 2$ dan penduduk sebanyak 1.504 jiwa, mereka sudah mengajukan proposal pemekaran dan katanya berkas pemekaranya sudah sampai di meja gubernur, bersamaan dengan proposal pemekaran Desa Karang Mulya. Tidak hanya itu, beberapa desa di kecamatan lain juga sudah melakukan proses perencanaan untuk pemekaran wilayah desa/kelurahan. Namun karena keterbatan data penulis perihal persoalan ini, tidak banyak analisis yang bisa diberikan. Hanya saja poin utama yang ingin disampaikan bahwa pemerintah daerah harus menyikapi serius atas aspirasi pemekaran desa karena inilah yang akan menjadi modal utama kelak untuk pemekaran kecamatan, utamanya Kecamatan Kotawaringin Lama dan Kecamatan Pangkalan Banteng yang butuh 3 desa/kelurahan lagi agar bisa melakukan pemekaran kecamatan.

\section{Analisis Kualifikasi Syarat Pemekaran}

Dari pemaparan sebelum, jelas terlihat bahwa rencana pemekaran kecamatan akan dilangsungkan untuk dua wilayah, yakni Kecamatan Kumai dan Kecamatan Arut Selatan. Pada bagian ini, rencana pemekaran kedua kecamatan tersebut akan diuji kualifikasinya, apakah sudah memenuhi syarat atau belum. Dalam melakukan uji kualifikasi, ada tiga kualifikasi yang akan di analisis, yakni kualifikasi persyaratan dasar, persyaratan teknis, dan persyaratan administratif. Ketiga kualifikasi persyaratan ini harus dianalisis untuk mengetahui mana yang sudah memenuhi syarat, mana yang belum memenuhi.

\section{a) Kualifikasi Persyaratan Dasar Pemekaran Kecamatan}

Kualifikasi persyaratan dasar adalah ketentuan mutlak terkait syaratsyarat minimal yang harus dipenuhi sebelum sebuah kecamatan melakukan pemekaran. Ada 4 variabel yang harus dilihat dalam kualifikasi dasar ini, yakni jumlah penduduk minimal, luas wilayah minimal, usia minimal kecamatan induk, dan jumlah minimal desa/kelurahan. Dalam PP Nomor 17 Tahun 2018 disebutkan bahwa pembentukan kecamatan baru (di Provinsi Kalimatan Tengah) harus memiliki penduduk per desa sebanyak 1.500 penduduk atau $300 \mathrm{KK}$, sedangkan untuk kelurahan sebanyak 2.000 penduduk atau $400 \mathrm{KK}$. Adapun untuk luas kecamatan baru harus lebih dari 12,5 $\mathrm{Km} 2$, dengan cakupan wilayah minimal 10 desa/kelurahan, serta usia kecamatan induk telah lebih dari 5 tahun. 
Sebelum mengukur keempat variabel di atas, yang perlu dilihat pertama kali adalah gambaran dasar atas luas wilayah, jumlah penduduk, dan jumlah KK yang ada dalam wilayahwilayah yang akan dimekarkan, baik di Kecamatan Arut Selatan maupun Kecamatan Kumai. Adapun gambaran umum wilayah yang akan dimekarkan ada pada tabel 5 dan 6 .

Tabel 5. Gambaran Wilayah Hasil Pemekaran Kecamatan Arut Selatan

\begin{tabular}{|c|c|c|c|}
\hline Desa/Kelurahan & Luas (Km2) & $\begin{array}{c}\text { Jumlah } \\
\text { Penduduk }\end{array}$ & $\underset{\text { KK }}{\text { Jumlah }}$ \\
\hline \multicolumn{4}{|c|}{ Kecamatan Arut Selatan (Induk) } \\
\hline $\begin{array}{l}\text { Desa Kumpai Batu } \\
\text { Bawah }\end{array}$ & 18,25 & 2.063 & 575 \\
\hline $\begin{array}{l}\text { Desa Kumpai Batu } \\
\text { Atas }\end{array}$ & 30 & 3.037 & 808 \\
\hline Desa Pasir Panjang & 162 & 11.218 & 3.194 \\
\hline Kelurahan Mendawai & 469 & 11.711 & 3.303 \\
\hline $\begin{array}{l}\text { Kelurahan Mendawai } \\
\text { Seberang }\end{array}$ & 26 & 2.217 & 609 \\
\hline Kelurahan Raja & 1.5 & 6.818 & 1.856 \\
\hline Kelurahan Sidorejo & 6 & 18.492 & 5.024 \\
\hline Kelurahan Madurejo & 26 & 19.931 & 5.503 \\
\hline Kelurahan Baru & 8.5 & 24.324 & 6.121 \\
\hline $\begin{array}{l}\text { Kelurahan Raja } \\
\text { Seberang }\end{array}$ & 115 & 1.748 & 461 \\
\hline Total & 862,25 & 101.559 & $\mathbf{2 7 . 4 5 4}$ \\
\hline \multicolumn{4}{|c|}{ Kecamatan Arut Selatan (Pemekaran) } \\
\hline Desa Rangda & 51 & 1.458 & 437 \\
\hline Desa Kenambui & 320 & 701 & 189 \\
\hline Desa Runtu & 504 & 5.079 & 1.485 \\
\hline Desa Umpang & 609 & 1.188 & 325 \\
\hline Desa Natai Raya & 6.2 & 1.849 & 492 \\
\hline Desa Medang Sari & 9 & 1.458 & 459 \\
\hline Desa Natai Baru & 7.3 & 2.132 & 560 \\
\hline Desa Sulung & - & 1.020 & 307 \\
\hline Desa Purbasari & 21 & 2.845 & - \\
\hline Desa Nanga Mua & 444 & 2.843 & 821 \\
\hline Total & $1.971,5$ & 20.741 & 5.075 \\
\hline
\end{tabular}

Tabel 6. Gambaran Wilayah Hasil

Pemekaran Kecamatan Kumai

\begin{tabular}{|c|c|c|c|}
\hline $\begin{array}{c}\text { Nama } \\
\text { Desa/Kelurahan }\end{array}$ & Luas $\left(\mathrm{Km}^{2}\right)$ & $\begin{array}{l}\text { Jumlah } \\
\text { Penduduk }\end{array}$ & $\begin{array}{c}\text { Jumlah } \\
\text { KK }\end{array}$ \\
\hline \multicolumn{4}{|c|}{ Kecamatan Kumai (Induk) } \\
\hline Desa Sungai Sekonyer & 791 & 527 & 143 \\
\hline Desa Sungai Kapitan & 90 & 5.971 & 1.315 \\
\hline Kelurahan Kumai Hilir & 82 & 9.082 & 1.966 \\
\hline Desa Batu Belaman & 73 & 2.328 & 537 \\
\hline Desa Sungai Tendang & 52 & 3.747 & 867 \\
\hline Kelurahan Candi & 67 & 4.129 & 90 \\
\hline Kelurahan Kumai Hulu & 18 & 8.114 & 1.756 \\
\hline Desa Sungai Bedaun & 403 & 5.384 & 1.456 \\
\hline Desa Bumi Harjo & 27,62 & 5.690 & 1.541 \\
\hline Desa Pangkalan Satu & 16,38 & 2.393 & 607 \\
\hline Total & 1.620 & 47.365 & 10.278 \\
\hline \multicolumn{4}{|c|}{ Kecamatan Kumai (Pemekaran) } \\
\hline Desa Sungai Cabang & 333 & 1.113 & 231 \\
\hline Desa Teluk Pulai & 478 & 284 & 66 \\
\hline Desa Kubu & 122 & 3.990 & 763 \\
\hline Desa Sungai Bakau & 111 & 1.637 & 377 \\
\hline Desa Teluk Bogam & 82 & 1.395 & 345 \\
\hline Desa Keraya & 78 & 543 & 135 \\
\hline Desa Sebuai & 97 & 495 & 122 \\
\hline Desa Sebuai Timur & - & 242 & 64 \\
\hline Desa Tanjung Putri & 19 & 1.001 & 288 \\
\hline $\begin{array}{l}\text { Desa Tanjung } \\
\text { Terantang }\end{array}$ & 12,25 & 811 & 207 \\
\hline Total & $1.332,25$ & 11.511 & 2.598 \\
\hline
\end{tabular}

Dengan melihat tabel 5 dan 6, terlihat secara jelas luas wilayah, jumlah penduduk, dan jumlah KK relatif masih memadai untuk rencana pemekaran. Untuk Kecamatan Kumai, tampak bahwa rencana pemekaran akan membagi wilayah yang hampir sama luasnya. Hanya kosentrasi penduduk/KK di kecamatan induk jauh lebih besar dibanding dengan kecamatan pemekaran, atau sekitar 4 kali lipat dari jumlah penduduk di wilayah yang dimekarkan. Sedangkan untuk Kecamatan Arut Selatan terlihat bahwa kecamatan induk memiliki luas lebih kecil dari wilayah kecamatan pemekaran, atau 2 kali dari luas kecamatan pemekaran. Meskipun kecamatan induk memiliki luas yang lebih kecil, jumlah penduduknya relatif lebih besar, yakni 5 kali lipat jumlah penduduk di kecamatan pemekaran. 
Dari gambaran di atas, maka tim peneliti bisa menganalisis seberapa jauh kualifikasi dasar rencana pemekaran bisa dipenuhi. Adapun hasil analisis ini bisa dilihat pada tabel 7 dan 8 .

Tabel 7. Kualifikasi Persyaratan Dasar Pemekaran Kecamatan Arut Selatan

\begin{tabular}{|c|c|c|c|c|}
\hline $\begin{array}{c}\text { Kategori } \\
\text { Syarat }\end{array}$ & $\begin{array}{l}\text { Syarat } \\
\text { Minimal } \\
\end{array}$ & $\begin{array}{l}\text { Kecamatan } \\
\text { Induk }\end{array}$ & $\begin{array}{l}\text { Kecamatan } \\
\text { Pemekaran } \\
\end{array}$ & Keterangan \\
\hline $\begin{array}{c}\text { Jumlah } \\
\text { minimal } \\
\text { desa/ } \\
\text { kelurahan }\end{array}$ & $\begin{array}{c}\text { Minimal } 10 \\
\text { desa/ } \\
\text { kelurahan }\end{array}$ & $\begin{array}{c}\text { Ada } 4 \text { desa, } 6 \\
\text { kelurahan }\end{array}$ & Ada 10 desa & Terpenuhi \\
\hline $\begin{array}{l}\text { Jumlah } \\
\text { penduduk } \\
\text { minimal }\end{array}$ & $\begin{array}{c}\text { Memiliki } 1.500 \\
\text { penduduk atau } \\
300 \mathrm{KK} \text { untuk } \\
\text { desa, dan } 2.000 \\
\text { penduduk atau } \\
400 \mathrm{KK} \text { untuk } \\
\text { kelurahan } \\
\end{array}$ & $\begin{array}{l}\text { Total satu } \\
\text { kecamatan } \\
\text { ada } 10.278 \\
\text { KK atau rata. } \\
\text { rata } 1.027 \text { KK }\end{array}$ & $\begin{array}{c}\text { Total satu } \\
\text { kecamatan } \\
\text { ada 5.075 } \\
\text { KK atau } \\
\text { rata-rata } \\
508 \mathrm{KK}\end{array}$ & Terpenuhi \\
\hline $\begin{array}{c}\text { Luas } \\
\text { minimal } \\
\text { wilayah } \\
\end{array}$ & $12 \mathrm{Km}^{2}$ & $862,25 \mathrm{~km}^{2}$ & $1.971,5 \mathrm{~km}^{2}$ & Terpenuhi \\
\hline $\begin{array}{c}\text { Usia } \\
\text { minimal } \\
\text { kecamatan } \\
\text { induk }\end{array}$ & $\begin{array}{l}\text { Minimal } 5 \\
\text { tahun }\end{array}$ & $\begin{array}{c}\text { Lebih dari } 5 \\
\text { tahun }\end{array}$ & . & Terpenuhi \\
\hline
\end{tabular}

Dari Tabel 7, rencana pemekaran Kecamatan Arut Selatan nanti akan menyisakan wilayah kecamatan induk yang lebih kecil. Hal ini sangat mungkin terjadi karena kosentrasi penduduk hampir rata-rata terpusat di wilayah ibukota kabupaten, Pangkalan Bun, yang berada persis di Kecamatan Arut Selatan. Sedangkan wilayah kecamatan pemekaran akan dua kali lebih besar dari kecamatan induk, namun dengan jumlah penduduk yang hanya separo saja. Dengan adanya pemekaran kecamatan ini, diharapkan akan muncul pusat pertumbuhan baru di wilayah Arut Selatan bagian atas, yang selama ini cukup tertinggal, khususnya dari sisi ekonomi. Artinya, keberadaan unit pemerintahan baru disana akan memberikan daya dorong bagi prioritas pembangunan yang lebih serius, khususnya perbaikan infrastruktur publik seperti jalan, listrik dan perbaikan fasilitas pendidikan dan kesehatan.

Sedangkan untuk kualifikasi persyaratan dasar pemekaran Kecamatan Kumai, bisa dilihat dalam tabel berikut.

Tabel 8. Kualifikasi Persyaratan Dasar Pemekaran Kecamatan Kumai

\begin{tabular}{|c|c|c|c|c|}
\hline $\begin{array}{c}\text { Kategori } \\
\text { Syarat }\end{array}$ & $\begin{array}{l}\text { Syarat } \\
\text { Minimal }\end{array}$ & \begin{tabular}{|c|} 
Kecamatan \\
Indulk \\
\end{tabular} & \begin{tabular}{|l|} 
Kecamatan \\
Pemekaranan \\
\end{tabular} & Keterangan \\
\hline $\begin{array}{c}\text { Jumlah } \\
\text { minimal desa/ } \\
\text { kelurahan }\end{array}$ & $\begin{array}{l}\text { Minimal } 10 \\
\text { desal } \\
\text { kelurahan }\end{array}$ & $\begin{array}{l}\text { Add7 desa } \\
\text { dan3 } \\
\text { kelurahan }\end{array}$ & Add 10 desa & Terpenuhi \\
\hline $\begin{array}{c}\text { Jumlah } \\
\text { penduduk } \\
\text { minimal }\end{array}$ & $\begin{array}{c}\text { Memiliki 1.500 } \\
\text { penduduk atau } \\
300 \text { KK untuk } \\
\text { desa, dan } 2.000 \\
\text { penduduk atau } \\
400 \text { KK untuk } \\
\text { kelurahan }\end{array}$ & \begin{tabular}{|l} 
Total satu \\
kecamatan \\
ada 27.454 \\
KK atau \\
ratatrata \\
2.745 KK
\end{tabular} & $\begin{array}{l}\text { Total satu } \\
\text { kecammatan } \\
\text { add 2.598 } \\
\text { KK atau } \\
\text { rataratata } \\
\text { 260 KK }\end{array}$ & Terpenuhi \\
\hline $\begin{array}{c}\text { Luas wilayah } \\
\text { minimal }\end{array}$ & $12 \mathrm{~km}^{2}$ & $1.620 \mathrm{Km}^{2}$ & $\begin{array}{c}1,332,25 \\
\mathrm{~km}^{2}\end{array}$ & Terpenuhi \\
\hline $\begin{array}{c}\text { Usia minimal } \\
\text { kecematatan } \\
\text { induk }\end{array}$ & $\begin{array}{l}\text { Minimal } 5 \\
\text { tahun }\end{array}$ & $\begin{array}{c}\text { Lebihd dari } 5 \\
\text { tahun }\end{array}$ & $\begin{array}{c}\text { Tidak } \\
\text { disyarartkan }\end{array}$ & Terpenuhi \\
\hline
\end{tabular}

Berdasar tabel 8, dari sisi kualifikasi persyaratan dasar, rencana pemekaran Kecamatan Kumai relatif bisa dipenuhi. Kesepuluh desa yang berada di wilayah pemekaran memiliki tipologi yang hampir sama, yakni berada di wilayah sepanjang pesisir Laut Jawa. Hasil wawancara dengan multi-stakeholder, wilayah ini perlu dimekarkan karena tergolong sebagai 
kecamatan yang sudah berumur lama tetapi masih sedikit tertinggal dari sisi pembangunan. Wilayah ini sebenarnya memiliki potensi besar di bidang pariwisata, mengingat garis pantainya yang cukup panjang. Sayangnya, pariwisata di beberapa desa pesisir ini kurang berkembang karena infrastruktur jalan yang tidak terlalu bagus. Selain itu, hampir sebagian besar tanah di wilayah pesisir ini dimiliki secara perseorangan dan banyak pemukiman yang menutupi panorama keindahan pantai.

\section{b) Kualifikasi Persyaratan Teknis Peme-karan Kecamatan}

Sedangkan untuk kualifikasi teknis, ada beberapa variabel yang harus diuji, diantaranya (1) kemampuan keuangan daerah; (2) sarana dan prasarana pemerintahan; (3) kejelasan rencana wilayah pemekaran. Ketiga kualifikasi teknis ini harus terpenuhi lebih dahulu sebelum rencana pemekaran kecamatan ditindaklanjuti secara lebih serius.

Pertama, sisi kemampuan keuangan daerah diukur dari rasio belanja pegawai terhadap APBD dan besar rasionya tidak lebih dari 50 persen. Dengan merujuk pada besar APBD Kabupaten Kobar Tahun 2018 sebesar Rp 1.304.958.050.000,00, terlihat bahwa tidak sampai separo jumlah APBD digunakan untuk belanja pegawai, baik untuk gaji PNS maupun honor kegiatan. Hal ini ditunjukkan dari besar belanja pegawai untuk gaji PNS hanya sebesar $\mathrm{Rp}$ 455.470.091.399,00 (dalam Belanja Tidak Langsung/BTL) dan besar belanja pegawai untuk honor kegiatan hanya mencapai $\mathrm{Rp}$ 119.208.581.222,00 (dalam Belanja
Langsung/BL). Artinya, jika seluruh belanja pegawai digabung sekalipun (baik di BTL maupun BL) hanya mencapai Rp 574.678.672.621,00, atau hanya sekitar 31 persen dari keseluruhan APBD.

\section{Gambar 1. Rasio Belanja Pegawai dalam} APBD Kabupaten Kobar 2018

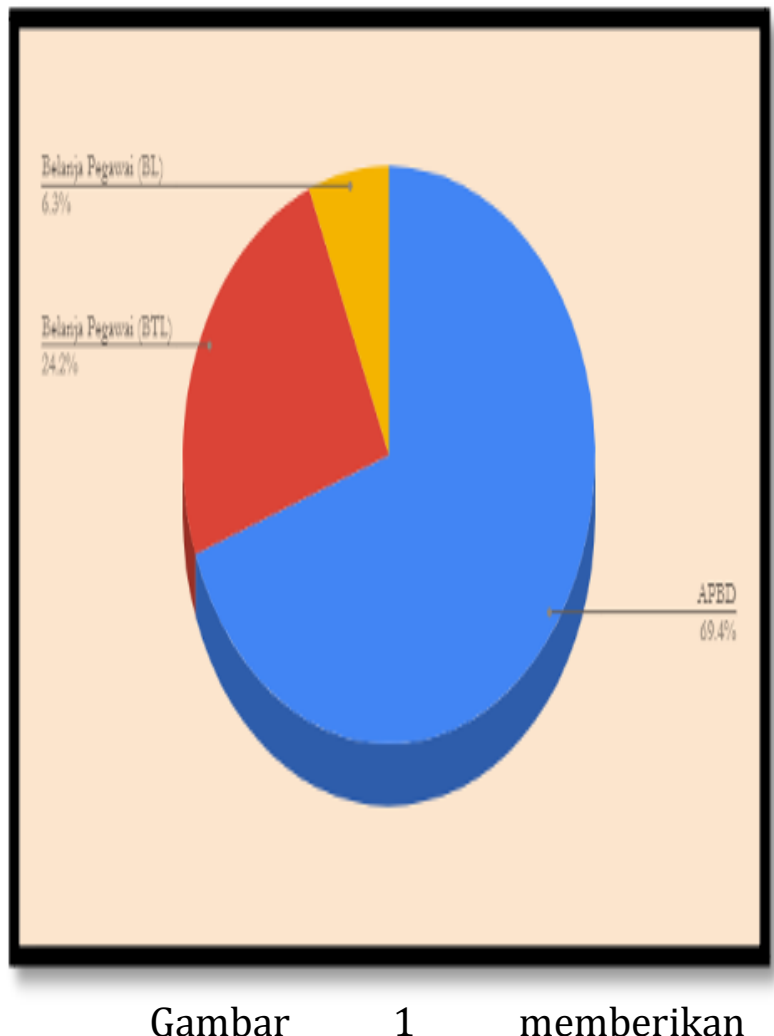

gambaran bahwa kemampuan keuangan daerah Kabupaten Kobar cukuplah kuat. Jumlah belanja pegawai yang masih relatif kecil merupakan keuntungan tersendiri bagi Kabupaten Kobar dalam rencana pemekaran kecamatan. Upaya menambah kecamatan baru dengan pemekaran, tidak akan membebani anggaran secara signifikan, mengingat hanya dua kecamatan saja yang akan dimekarkan. Kenyataan ini mengkonfirmasi bahwa persyaratan teknis kemampuan keuangan daerah dalam rencana pemekaran dua 
kecamatan di Kabupaten Kobar telah terpenuhi.

Kedua, untuk kualifikasi teknis berupa sarana dan prasarana pemerintahan, juga relatif lebih mudah terpenuhi. Dalam PP Nomor 17 Tahun 2018, kualifikasi ini mengatur setidaknya sudah memiliki lahan untuk kantor camat dan lahan untuk sarana dan prasarana pendukung pelayanan publik lainnya. Meskipun penulis belum sampai memetakan potensi lahan yang ada, namun observasi secara umum di Kabupaten Kobar hampir setiap desa memiliki lahan desa yang relatif luas. Meskipun jumlah lahan kas desa di Kabupaten Kobar juga menyempit sebagaimana terjadi di Jawa, namun secara umum desa masih memiliki tanah desa yang mencukupi apabila akan dipakai untuk pembangunan sarana prasarana kecamatan baru.

Dengan menggunakan asumsi luas lahan kantor kecamatan di Jawa yang paling luas hanya sekitar 2.500 meter persegi (Kantor Kecamatan Semarang Tengah saja hanya $1.563 \mathrm{~m} 2$ ), maka membangun kantor kecamatan baru di Kabupaten Kobar (plus dengan sarana-prasarana seperti rumah dinas, fasilitas kesehatan dan pendidikan, instansi vertikal, dan fasilitas pendukung kegiatan sosial dan ekonomi), luas lahan sekitar $3 \mathrm{Ha}$ (30.000 m2) sudah lebih dari cukup. Mendapatkan tanah (kas) desa seluas 3 sampai 5 Ha dalam konteks Kabupaten Kobar adalah jauh lebih mudah daripada mecari tanah seluas itu di Jawa, mengingat desa-desa di sana masih memiliki tanah desa yang relatif luas. Seandainya ibukota kecamatan pemekaran dari Kecamatan Arut Selatan ada di Desa Runtu, maka mencari lahan sekitar 3 Ha bukan hal yang sulit, karena luas wilayah Desa Runtu mencapai $50.400 \mathrm{Ha}$ atau lebih dari 10 kali luas wilayah Kota Surakarta (4.601 Ha). Apalagi untuk Desa Teluk Bogam, seandainya pemekaran Kecamatan Kumai memilih desa ini sebagai ibukota kecamatan baru, maka telah disiapkan lahan seluas 25 Ha sebagaimana disampaikan Kepala Desa Teluk Bogam pada tim peneliti.

Dari sini bisa disimpulkan bahwa syarat kualifikasi teknis berupa kesiapan lahan untuk pembangunan sarana prasarana kecamatan baru diasumsikan bisa terpenuhi. Jika hanya ketersediaan lahan, maka besar kemungkinan hal ini tidak akan menjadi persoalan. Apalagi ini merupakan penelitian tahap awal, dimana proses rencana pemekaran belum sampai pada tahap yang lebih kongkret. Rencana pemekaran masih menjadi wacana, belum sampai pada sosialisasi dan komunikasi ke bawah apalagi proses politik yang nyata yang terekspresikan dalam forum-forum desa atau kecamatan. Oleh karena itu, kendala terbesar sebenarnya yang akan muncul adalah dimana posisi ibukota kecamatan. Inilah yang akan menjadi persoalan karena akan muncul banyak aspirasi dari masing-masing desa/kelurahan yang mengajukan diri menjadi ibukota kecamatan.

Sedangkan untuk kualifikasi teknis yang ketiga, yakni kejelasan perencanaan wilayah pemekaran, terdapat 4 variabel yang haris diuji sebagaimana tertuang dalam Pasal 5 Ayat (4) PP Nomor 17 Tahun 2018. Adapun ke-4 variabel itu, diantaranya: 
(1) kejelasan batas wilayah kecamatan dengan menggunakan titik koordinat sesuai dengan ketentuan peraturan perundang-undangan; (2) nama kecamatan yang akan dibentuk; (3) lokasi calon ibu kota Kecamatan yang akan dibentuk; dan (4) kesesuaian dengan rencana tata ruang wilayah. Meskipun belum bisa diukur secara pasti terkait kualifikasi ini, bukan berarti kualifikasi persyaratan teknis tentang kejelasan perencanaan wilayah pemekaran tidak bisa digambarkan. Untuk itu, penulis akan memberikan gambaran bagaimana problem yang dihadapi untuk memenuhi kualifikasi ini. Secara sederhana, gambaran tantangan untuk memenuhi kualifikasi persyaratan teknis bisa dilihat pada tabel 9.

Tabel 9. Pemenuhan Persyaratan Teknis terkait Rencana Wilayah Pemekaran

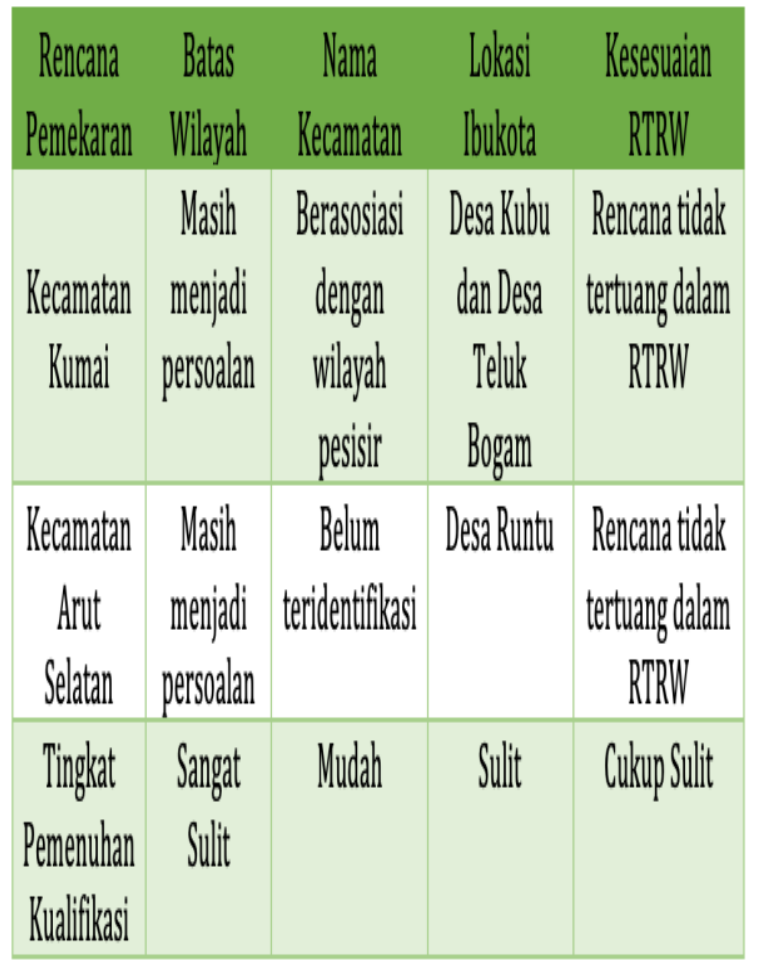

Untuk rencana pemekaran kecamatan ini, tantangan yang paling sulit adalah menentukan batas wilayah pemekaran. Hasil elaborasi dari wawancara dengan multi-stakeholder di Kabupaten Kobar, ditemukan kenyataan bahwa hampir setiap desa/kelurahan masih banyak yang belum menyelesaikan masalah tapal batas antar wilayahnya. Beberapa diantaranya seperti, Desa Tanjung Putri yang sampai sekarang belum menemukan kesepakatan batas wilayah dengan Desa Sebuai di Kecamatan Kumai. Kemudian Desa Kubu di Kecamatan Kumai yang masih bermasalah terkait batas desanya dengan Desa Pasir Panjang di Kecamatan Arut Selatan. Juga Kelurahan Mendawai yang masih belum bersepakat dalam hal batas wilayah dengan Desa Tanjung Putri dan Desa Kumpai Batu Bawah. Bahkan, Desa Sungai Sekonyer masih bersengketa wilayah dengan desa-desa di Kabupaten Seruyan. Kenyataan seperti ini nyaris ditemukan disetiap wawancara dengan warga atau perangkat desa/kelurahan di Kabupaten Kobar.

Ada atau tidak ada pemekaran, persoalan tapal batas wilayah ini harus segera diselesaikan. Pemerintah daerah dan perangkatnya harus turun tangan dan turun lapangan untuk menyelesaikan persoalan ini. Momen rencana pemekaran kecamatan adalah waktu yang tepat untuk melakukan kesepahaman bersama terkait batas wilayah. Pemerintah daerah bisa membiayai kegiatan pemetaan partisipatif antar desa, selain untuk mendapatkan kejelasan batas wilayah, juga untuk mendata sejumlah aset dan peta persoalan yang masih menjadi 
persengketaan antar desa. Pemetaan partisipatif yang biasa digunakan NGO, sangat relevan dilakukan untuk menyelesaikan persoalan ini.

Sedangkan untuk nama kecamatan tentu saja hal yang mudah. Ketika proses sosialisasi dan forum-forum desa/kelurahan sudah digalakkan, maka imaji tentang nama kecamatan baru akan bisa disepakati dengan cepat. Misalkan untuk pemekaran Kecamatan Kumai, tim peneliti seringkali mendengar aspirasi penamakan kecamatan baru itu dengan nama Kecamatan Pesisir atau Kecamatan Kumai Pesisir. Nama ini muncul karena wilayah baru yang akan dimekarkan ini berada persis di sepanjang pesisir Laut Jawa, Kabupaten Kobar. Sedangkan untuk penamaan calon kecamatan baru dalam pemekaran Kecamatan Arut Selatan, tim peneliti belum mendapatkan aspirasi yang memadai.
Jauh yang lebih sulit dibanding memilih nama adalah menentukan ibukota kecamatan. Sebab, penempatan ibukota kecamatan di desa tertentu sama artinya dengan memudahkan beberapa desa, tetapi juga menyulitkan beberapa desa lainnya. Untuk memudahkan ilustrasi persoalan penentuan ibukota pemekaran Kecamatan Kumai, peta di bawah ini akan bisa membantu menyederhanaan persoalan. Jika Desa Kubu menjadi ibukota kecamatan baru, maka akan muncul suara penolakan dari Desa Tanjung Terantang, Tanjung Putri, Sabuai, Sabuai Timur, Keraya, Teluk Bogam, dan Sungai Bakau. Ini sangat mungkin terjadi karena mereka tetap merasa pemekaran tidak akan mendekatkan akses apapun terhadap wilayahnya.

Gambar 2. Potensi Konflik Penentuan Calon Ibukota Pemekaran Kecamatan Kumai

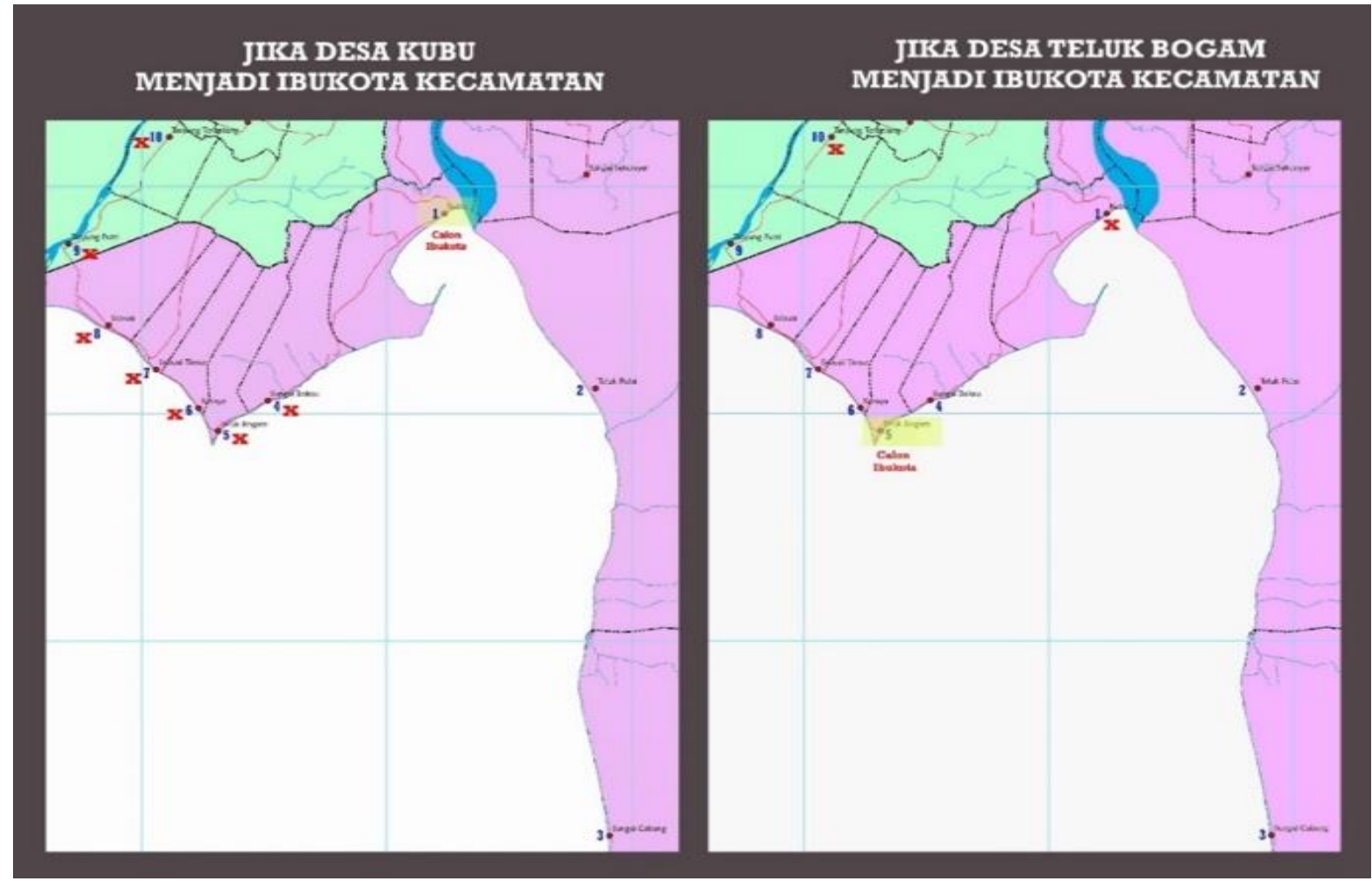


Begitu juga ketika calon ibukota di tempatkan di Desa Teluk Bogam, Desa Kubu akan cenderung menolak karena mereka lebih nyaman untuk datang ke Kumai (Kelurahan Candi) daripada harus ke Desa Teluk Bogam. Sedangkan Desa Tanjung Terantang, baik di Kubu atau Teluk Bogam, rencana pemekaran ini hanya dinilai semakin membuat sulit akses mereka dibandingkan harus ke Pangkalan Bun di Arut Selatan. Adapun Desa Teluk Pulai dan Desa Sungai Cabang, mereka akan tetap merasa terisolir dimanapun ibukota kecamatan baru di tempatkan, meskipun besar kemungkinan mereka akan lebih memilih Desa Kubu sebagai ibukota kecamatan yang baru. Khusus untuk Desa Teluk Pulai dan Desa Sungai Cabang, sudah semestinya kedua desa ini mendapat perhatian jauh lebih serius, baik pemerintah daerah maupun pemerintah pusat mengingat lokasi mereka yang sangat terisolir.

Sedangkan untuk rencana pemekaran Kecamatan Arut Selatan, keadaannya jauh lebih kompleks. Sebab, tidak ada satu pilihan pun yang bisa diterima dengan mudah oleh semua pihak. Secara geografis, hasil dari rencana wilayah pemekaran ini masih terlampau luas, yakni mencapai 1.971,5 Km2 atau lebih dari 5 kali luas Kota Semarang $\quad\left(373,8 \mathrm{~km}^{2}\right)$. Gambaran sederhannya bisa dilihat di gambar 2 .

Dari gambar 3, setidaknya ada 4 desa yang akan merasa dirugikan oleh adanya pemekaran (bertanda X, warna merah), yakni Desa Nanga Mua, Desa Purbasari, Desa Natai Baru, dan Desa Natai Jaya. Anggaplah ibukota kecamatan ada di Desa Runtu atau dimanapun kecuali ke-4 desa tersebut, maka ke-4 desa ini akan tetap sulit menerima posisi ibukota kecamatan yang baru. Desa Nanga Mua akan merasa dirugikan karena akses jalan darat relatif belum ada untuk ke desadesa lainnya di Arut Selatan. Begitu juga dengan Desa Purbasari (di Kecamatan Pangkalan Lada), Desa Natai Baru dan Desa Natai Jaya (Kecamatan Arut Selatan), kenyataan harus berpindah dari kecamatan induknya akan membuat mereka semakin sulit mendapatkan akses. Sebab jarak ke Desa Runtu lebih jauh dibanding harus ke Kelurahan Pandu Senjaya atau ke Pangkalan Bun sekalipun.

Gambar 3. Potensi Konflik dalam Penentuan Calon Ibukota Pemekaran Kecamatan Kumai

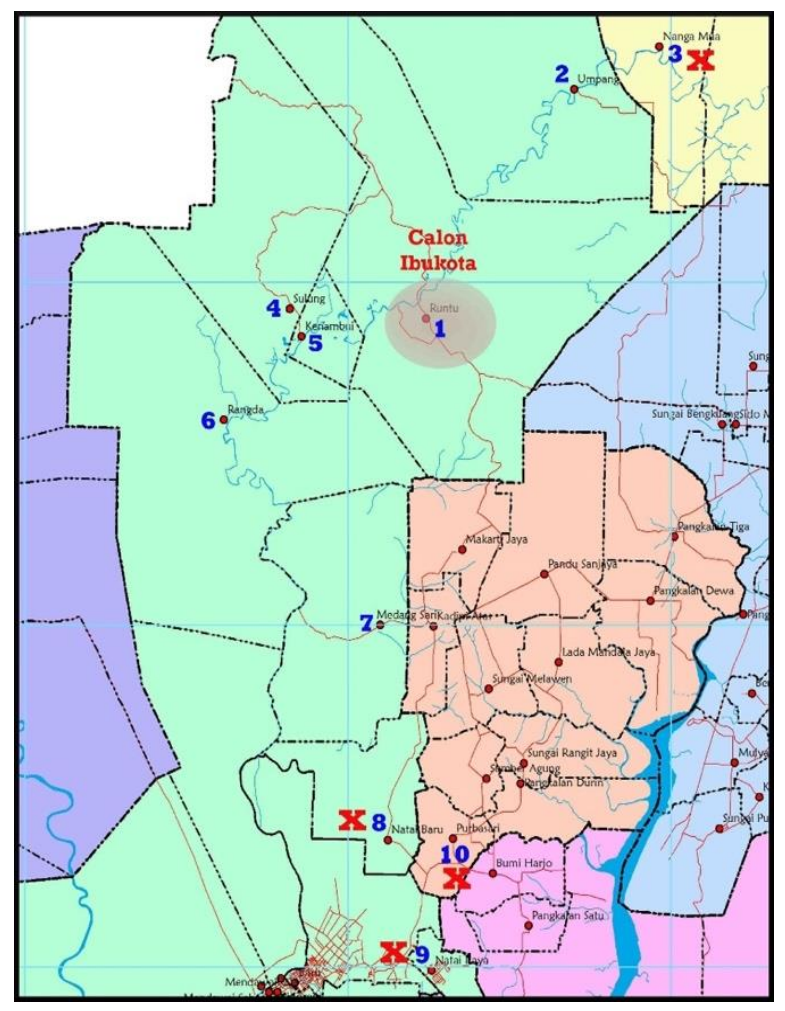

Pemaparan di atas menunjukkan bahwa penentuan ibukota kecamatan baru, baik untuk rencana pemekaran Kecamatan Kumai maupun Kecamatan 
Vol.2 No.2 Desember 2020

Arut Selatan akan jauh lebih sulit. Tidak ada satu pun pilihan calon ibukota yang bisa begitu saja diterima oleh semua pihak. Untuk itu, pemerintah daerah harus memainkan peran yang signifikan dan serius guna mencari jalan resolusi yang terbaik. Komunikasi dan sosialisasi yang transparan dan akuntabel adalah kunci keberhasilan untuk memecahkan persoalan calon ibukota kecamatan baru ini.

Adapun kesesuaian rencana pemekaran dengan RTRW, tim peneliti tidak menemukan adanya ekuivalensi sama sekali. Dalam Perda Nomor 1 Tahun 2018 tentang Rencana Tata Ruang Wilayah Kabupaten Kotawaringin Barat Tahun 2017-2037, tidak termuat satu pasal pun yang mengatur rencana pemekaran kecamatan di Kabupaten Kobar. Hal ini cukup disayangkan mengingat rencana pemekaran kecamatan sudah digaungkan sejak lama, namun Perda RTRW yang baru disahkan pada 2018 tidak mencantumkan rencana itu sama sekali. Namun hal ini sebenarnya bukan murni kesalahan pemerintah daerah, karena aturan ini pemekaran kecamatan, yakni PP Nomor 17 Tahun 2018 juga baru dikeluarkan pemerintah pusat Agustus 2018 lalu, dimana aturan sebelumnya tidak memuat ketentuan ini.

Selain itu, dalam aturan tersebut juga tidak memberi penjelasan yang lebih mendetail lagi terkait apa yang dimaksud dengan "kesesuaian dengan rencana tata ruang wilayah". Untuk itu, penulis menafsirkan ini sebagai: Selama tidak ada ketentuan dalam Rencana Tata Ruang Wilayah (RTRW) yang dilanggar, maka rencana pemekaran kecamatan bisa dilakukan. Seandainya ketentuan ini mensyaratkan bahwa rencana pemekaran wilayah harus tersurat dalam RTRW, maka pemerintah daerah dan DPRD Kabupaten Kobar harus menyikapinya dengan usulan revisi perda. Karenanya, untuk variabel ini tim peneliti hanya mengkategorikan sebagai cukup sulit, maksudnya perlu usaha untuk merevisi perda jika memang disyaratkan demikian.

\section{c) Kualifikasi Persyaratan Administratif Pemekaran Kecamatan}

Kualifikasi administratif yang dimaksud dalam PP Nomor 17 Tahun 2018 adalah kesepakatan musyawarah desa dan/atau keputusan forum komunikasi kelurahan, baik di kecamatan induk maupun kecamatan baru yang akan dimekarkan. Kesepakatan pemekaran ini harus diputuskan secara bersama oleh pejabat atau perwakilan desa/kelurahan dalam sebuah berita acara. Artinya, forum ini harus dihadiri oleh semua desa/kelurahan yang akan masuk dalam rencana pemekaran. Merujuk pada pengertian itu, maka tim peneliti menyimpulkan bahwa kualifikasi ini belum terpenuhi karena proses rencana pemekaran masih pada tahap penjajakan, belum sampai pada sosialisasi dan komunikasi nyata tentang desa/kelurahan mana yang akan menjadi bagian dari kecamatan yang baru.

Meskipun kualifikasi ini belum terpenuhi, namun tim peneliti menemukan kenyataan bahwa hampir semua pihak yang berhasil ditemui sebagian besar menyatakan dukungannya terhadap rencana 
pemekaran ini. Wawancara tim peneliti dengan Wakil Bupati Kobar, Ahmadi Riansyah dan Ketua DPRD Kobar, Triyanto dalam tempat dan waktu yang terpisah menunjukkan adanya kepaduan gagasan yang solid perihal rencana pemekaran. Mereka berdua sama-sama mendukung rencana pemekaran kecamatan mengingat dua kabupaten pemekaran dari Kabupaten Kobar, yakni Kabupaten Lamandau dan Kabupaten Sukamara memiliki jumlah kecamatan yang jauh lebih banyak. Artinya, political will dari pihak eksekutif dan legislatif harus didorong dalam aksi nyata dengan menginisiasi forum-forum desa atau kelurahan.

Tidak hanya pucuk pimpinan daerah, wawancara dan focus group discussion (FGD) yang dilakukan tim peneliti dengan birokrat-birokrat pemerintah daerah, beberapa camat, dan belasan perangkat desa, serta tokoh-tokoh masyarakat, menunjukkan bahwa rencana pemekaran mendapat dukungan solid. Hal ini terjadi karena sebaran kue pembangunan yang tidak merata akibat wilayah administratif yang hanya 6 kecamatan harus menaungi wilayah yang terlampau luas. Di titik ini bisa disimpulkan bahwa kualifikasi administratif berupa kesapakatan forum desa/kelurahan meskipun belum dilakukan, bukan hal yang sulit untuk ditindaklanjuti. Sebab, kebutuhan pemekaran kecamatan sudah menjadi imaji bersama warga Kotawaringin Barat, dari kepala daerah hingga masyarakat akar rumput.

\section{E. SIMPULAN DAN SARAN}

Berdasarkan pembahasan di atas, maka pemekaran kecamatan dan desa di Kabupaten Kotawaringin Barat adalah sesuatu yang tidak terhindarkan lagi. Konteks pemekaran ini jelas berkaitan dengan gagasan dan keinginan untuk memperdekat pelayanan publik sekaligus menyiapkan berbagai instrumen kebijakan untuk mendorong terjadinya pemerataan pembangunan. Hasil analisis kesesuaian existing condition dengan tata aturan pemekaran, maka ada dua agenda yang bisa dilakukan. Pertama, untuk jangka pendek, diperlukan adanya penataan ulang jumlah administratif kecamatan. Hasil analisis menunjukkan bahwa Kecamatan Kumai dan Arut Selatan bisa ditata ulang menjadi dua kecamatan baru karena syarat dasar administratif telah terpenuhi. Kedua, dalam jangka panjang, setidaknya ada 26 desa/kelurahan yang berpotensi untuk dimekarkan karena memenuhi syarat dasar sesuai regulasi. Sedangkan dari sisi kualifikasi, baik syarat dasar, teknis, maupun administrasi, setidaknya ada dua kecamatan baru yang bisa dimekarkan dan memenuhi ketiga kualifikasi tersebut.

Dari hasil analisis di atas, artikel ini menunjukkan sebuah signifikansi bahwa tata aturan yang di terkait pemekaran kecamatan dan desa, terlihat sangat tidak cocok untuk konteks Pulau Kalimantan. UU No 9/2015 tentang Pemerintah Daerah, UU No.6 Tahun 2014 tentang Desa dan PP Nomor 17 Tahun 2018 tentang Kecamatan, memiliki kecenderungan kontekstualisasi hanya pada Pulau Jawa (Jawa Sentris). Sebaliknya, penentuan kategori jumlah penduduk minimal, luas wilayah minimal, usia minimal kecamatan induk, dan jumlah minimal 
Vol.2 No.2 Desember 2020

desa/kelurahan adalah kategori yang sangat sulit diikuti dalam konteks Pulau Kalimantan. Argumen ini di dasarkan pada sulitnya merancang skenario agar pemekaran desa dan kecamatan di Kabupaten Kotawaringin Barat bisa terpenuhi.

Karena itulah, analisis tulisan ini dilabeli sebagai sebuah skenario saja, yakni untuk menyesuaikan tata aturan administratif sesuai undang-undang dengan data-data agregat terkait kondisi terkini masing-masing kecamatan. Skenario ini tentu saja bukan elaborasi fakta di lapangan, yang bisa jadi memiliki dinamika jauh lebih kompleks dan rumit. Selain itu, penelitian ini memiliki limitasi terkait dengan pengayaan yang dikerjakan dengan mengandalkan data statistik tahun 2017. Artinya, ada potensi perubahan data (terbaru) akan ikut mempengaruhi hasil analisis yang berbeda, khususnya terkait bagaimana skenario pemekaran dirumuskan.

\section{UCAPAN TERIMA KASIH}

Penulis mengucapkan terima kasih kepada Pemerintah Daerah Kabupaten Kotawaringin Barat, Provinsi Kalimantan Tengah yang telah memfasilitasi penelitian ini, dan juga kepada Eni Lestari dan Budi Baskoro yang telah menjadi asisten lokal dan membantu secara signifikan proses penelitian lapangan.

\section{DAFTAR PUSTAKA}

Bustami, E. (2018). Analisis Dampak Pemekaran Desa terhadap Pembangunan Infstruktur di Desa Sungai Bendung Air Kecamatan Kayu Aro. Jurnal Administrasi
Nusantara, 1(2), 1-15.

Harahap, S. A. W. (2015). Dampak Pemekaran Desa Dalam

Pembanguuan Infrastruktur (Studi Kasus Pada Desa Penampaan Uken Kecamatan Blangkejeren Kabupaten Gayo Lues). Perspektif, 4(1).

Kartini, F. (2016). Dampak Kebijakan

Pemekaran Desa Pada Aspek

Pelayanan Publik di Desa Sadar Kecamatan. Fakultas Ilmu Sosial, Universitas Negeri Makasar.

Kompas.com. (2020). Wapres:

Moratorium Pemekaran Daerah karena Keuangan Negara Belum Memungkinkan. Kompas.Com. https://nasional.kompas.com/read /2020/10/01/17540771/wapresmoratorium-pemekaran-daerahkarena-keuangan-negara-belummemungkinkan

Lutpiah, M. (2016). Pemekaran Desa dan Implikasinya Terhadap Kehidupan Masyarakat (Studi Kasus di Desa Kramat Jaya Kecamatan Malausma Kabupaten Majalengka). ORASI: Jurnal Dakwah Dan Komunikasi, 7(2).

Mudana, M., Nempung, T., \& Millia, H. (2016). Dampak Pemekaran Desa Terhadap Pembangunan Infrastruktur di Desa Kapu Jaya Kecamatan Palangga Kabupaten Konawe Selatan. Jurnal Ekonomi UHO, 1(1).

Panambunan, G. A. A. G., Pangemanan, P. A., \& Sagay, B. A. B. (2018). Dampak Pemekaran Desa terhadap Infrastruktur Desa pakuure Dua Kecamatan Tengah Kabupaten Minahasa Selatan. Agro- 
Vol.2 No.2 Desember 2020

Sosioekonomi, 14(1), 231-240.

Polakitang, R. (2013). Dampak

Pemekaran Wilayah Terhadap

Pelayanan Publik (Studi Pelayanan

Publik Dalam Sektor Pendidikan

Pasca Pemekaran Wilayah di

Kabupaten Talaud). Jurnal

Eksekutif, 2(1).

Riani, I. A. P., \& Pudjihardjo, M. (2012).

Analisis Dampak Pemekaran

Wilayah Terhadap

PendapatanPerkapita, Kemiskinan,

Dan Ketimpangan Antar Wilayah di

Provinsi Papua. Jurnal Bumi Lestari, 12(1), 137-148.

Santika, R. H., Santoso, B., \& Mahmudi, H. (2018). Analisis Dampak Pemekaran Daerah Terhadap Kinerja dan Pemerataan Ekonomi di Kabupaten Lombok Utara. JIP (Jurnal Ilmu Pemerintahan): Kajian Ilmu Pemerintahan Dan Politik Daerah, 3(1), 15-23.

Setkab.go.id. (2019). Usulan 314 DOB Dikaji, Mendagri: Pemerintah Tetap Berlakukan Moratorium Pemekaran Daerah. Setkab.Go.Id. https://setkab.go.id/usulan-314dob-dikaji-mendagri-pemerintahtetap-berlakukan-moratoriumpemekaran-daerah/

Yosephus, S. (2014). Dampak Pemekaran Wilayah Terhadap Pelayanan Publik (Suatu Studi Di Kantor Kecamatan Tombariri Timur Dalam Pelayanan Administrasi Pengurusan Kartu Keluarga). Jurnal Politico, 3(1). 